\title{
Necrotized Facial Deformities in an Urban Population of Common Snapping Turtles (Chelydra serpentina, Chelydridae) from Bronx, New York
}

Erik Zeidler, New York Wild! (www.ny-wild.com), Bronx, New York 10461 (erik.zeidler@ny-wild.com)

Photographs by the author except where indicated.

$\mathrm{B}$ one pathologies have been well documented in turtles, but most affect the shell and originate during embryonic development or subsequent poor care in captivity (Bell et al. 2006, McArthur et al. 2010). Facial deformities have also been documented, but most have been attributed to improper captive care, particularly when the turtles were juveniles.

Bell et al. (2006) conducted a thorough study of the incidences and probable causes of embryonic deformity in urban (Philadelphia, Pennsylvania) populations of Painted Turtles (Chrysemys picta) and Common Snapping Turtles (Chelydra serpentina). Croteau et al. (2008) reviewed the considerable toxicological issues potentially affecting especially aquatic species of herpetofauna in urban environments.

Although less thoroughly documented, bone and softtissue pathologies in wild populations of turtles are a concern in chelonian conservation. Jacobson et al. (2000) briefly reviewed mycotic diseases of reptiles; I found no similar overview of bacterial agents.

\section{Methods}

In 2009-2010, I conducted a field study of Common Snapping Turtles (Chelydra serpentina) from the Bronx River and adjacent study sites in Bronx (New York City), New York (Fig. 1). I collected data from 285 specimens, all of which were greater than $102 \mathrm{~mm}$ in carapace length. Turtles smaller than that were captured occasionally but were not included at this stage of my study. All turtles captured were individually marked by notching marginal scutes (Cagle 1939).

\section{Results}

Females from the Bronx River population were significantly smaller than males (Figs. $2 \& 3$ ), although sexes did not differ significantly in body-mass-index (BMI) expressed as kg/ $\mathrm{cm}$ carapace length (Fig. 4). Of all turtles captured, five indi- viduals representing two sites (Table 1), showed pronounced necrotic facial conditions (2.5\% of the individuals captured). Four of these turtles were males and in the upper level of carapace length (and probably age) for the population. Although individuals M3 and M4 were noted as in the lower range of BMI, all four males were within population limits, as was the sole female.

Turtles with these deformities lose soft tissue and bone from their faces, resulting in apparently permanent damage. In severe cases (e.g., M1; Figs. 5a \& b), the entire front of the face was deteriorated, the eyes were swollen shut, and the nose was entirely missing. Large quantities of bone in the front of the skull (including sections of the prefrontal, maxilla, fossa nasalia, foramen praepalatinum, and the entire premaxilla and aperatura narium externa) were completely absent in some individuals. In other cases (Table 1; Figs. 6-9), the soft tissue

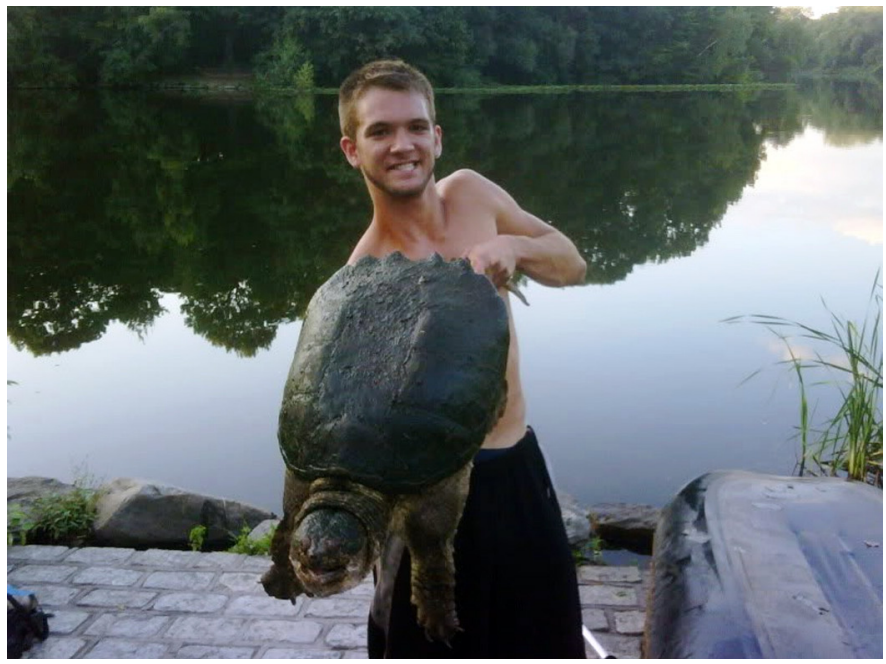

Fig. 1. The author with a 22.7-kg (50-lb) Common Snapping Turtle (Chelydra serpentina) from Van Cortland Park in Bronx, New York. Photograph by Rick Zeidler. 


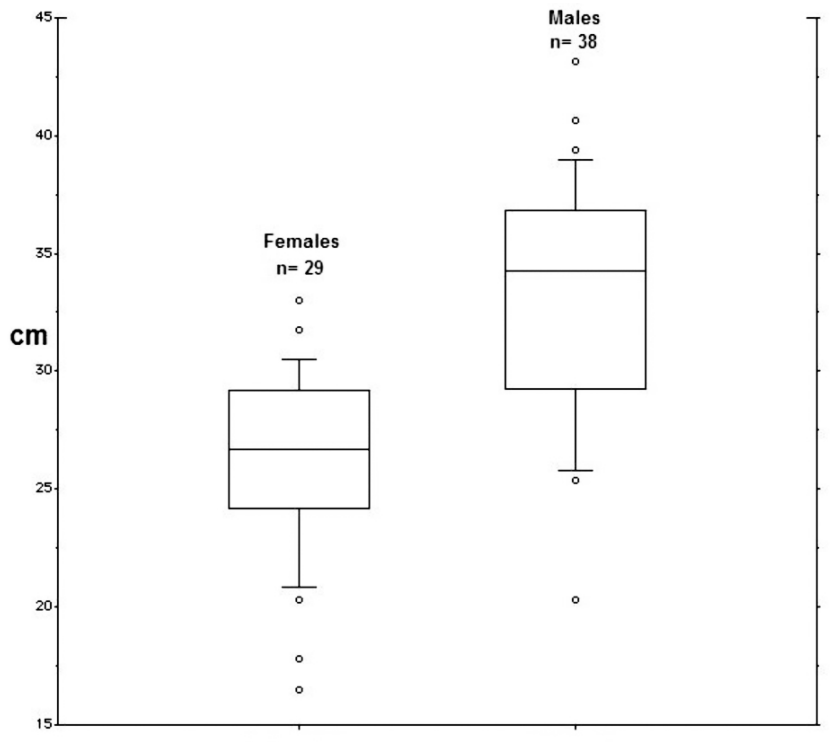

Fig. 2. Female and male carapace lengths $(\mathrm{cm})$ in adult Common Snapping Turtles (Chelydra serpentina) from the Bronx River. Female mean $=26.23$ $\pm 4.03 \mathrm{~cm}$; male mean $=33.09 \pm 5.41 \mathrm{~cm}$; Mann-Whitney $\mathrm{U}, \mathrm{Z}$ (corrected $)=-4.79, \mathrm{p}<0.01$.

in the nose was deteriorated, leaving the turtles with a single facial aperture where their nostrils once were.

Three turtles with facial necrosis (Table 1a) were found in the Bronx River, in the section running through the Bronx Zoo and the nearby New York Botanical Gardens (NYBG). Two were found within NYBG in a pond known as Twin Lakes, which is only about $90 \mathrm{~m}$ from the Bronx River. Of these five, two turtles, both with severe facial deformities, also exhibited other morphological abnormalities. One individual (M3) had a deformed front left foot, in which digits 1-3 were fused together. Digits 4 and 5 were barely recognizable and were fused together in a fleshy mass that grew separately from the rest of the foot (Fig. 10). Another individual with this condition (M4) also had damage to its shell, which was partially discolored and included necrotic areas. All five turtles were captured multiple times in 2009, and four of them were recaptured in 2010.

The first observed case of extensive facial necrosis was an adult male captured on 30 June 2009 (M4). This turtle was found resting on a bank about $5 \mathrm{~m}$ from the water. It was very weak, and only two-thirds the weight of other turtles its size. It was listless and appeared to be moribund.

The extent of facial tissue damage of a different individual (M1) that was recaptured in 2010 worsened from the previous year. When it was recaptured on 26 June 2010, it was in very bad overall condition. It was found buried in mud about $30 \mathrm{~cm}$ beneath the water's surface with only its head exposed, about $1.6 \mathrm{~km}$ from where it was found initially. Both eyes were swollen, with one entirely shut. It appeared to be completely blind. When first captured in 2009, the entire front of

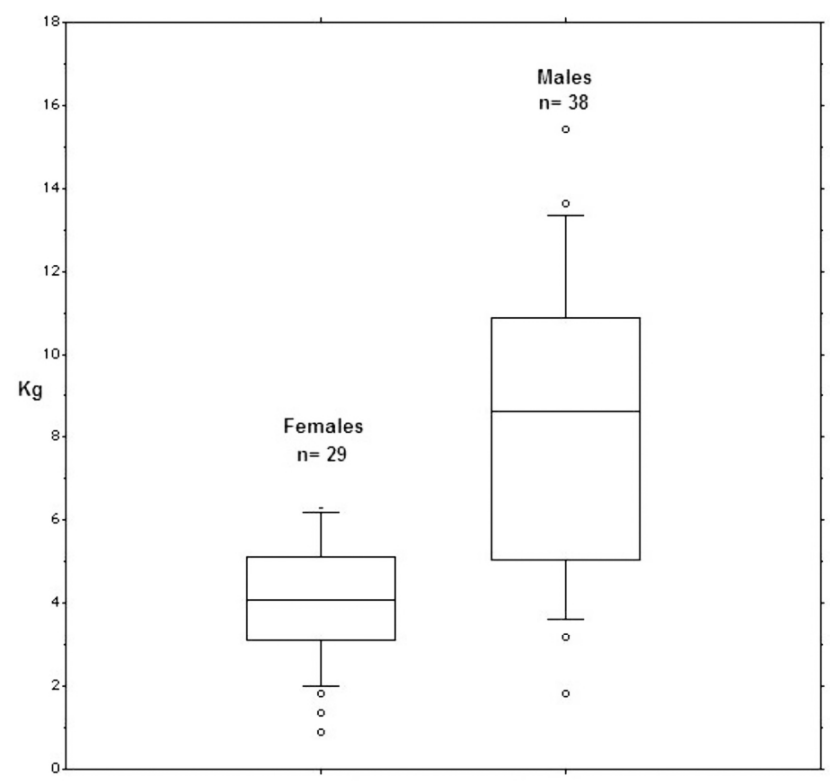

Fig. 3. Female and male mass $(\mathrm{kg})$ in Bronx River adult Common Snapping Turtles (Chelydra serpentina) from the Bronx River. Female mean $=4.0 \pm 1.53 \mathrm{~kg}$; male mean $=8.2 \pm 3.67 \mathrm{~kg}$; Mann-Whitney U, Z $($ corrected $)=-4.76, \mathrm{p}<0.01$.

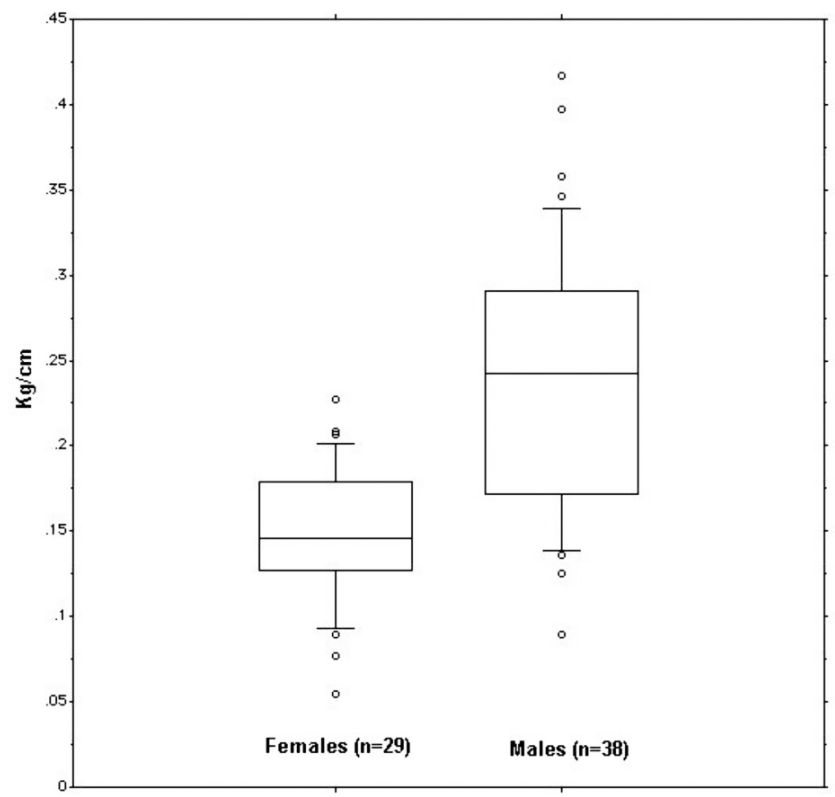

Fig. 4. Female and male body-mass index (mass/cm-carapace-length) in adult Common Snapping Turtles (Chelydra serpentina) from the Bronx River. Female mean $=0.15 \pm 0.04$; male mean $=0.24 \pm 0.08 ; \mathrm{p}(0.95)=$ n.s.

its face was gone. In 2010, more facial tissue had been lost, and the area around the front of the face was swollen and showed considerable inflammation; a peach-colored exudate covered much of the area that formerly was the animal's nose. The affected areas, which were once hard bone, were soft and rubbery.

Other deformities and abnormalities documented from this population included deformed feet, shells, and tails 
Table 1. Data for Common Snapping Turtles described in the text.

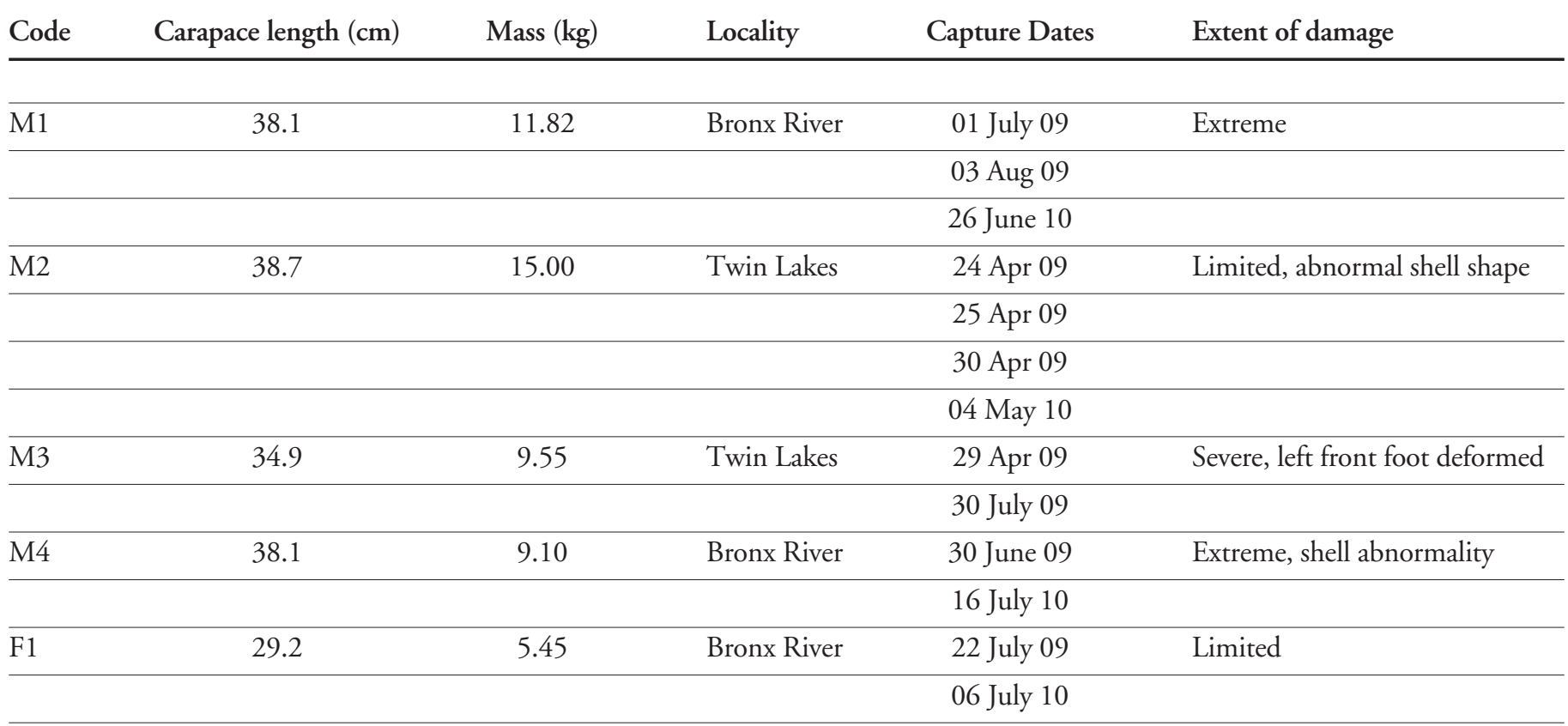

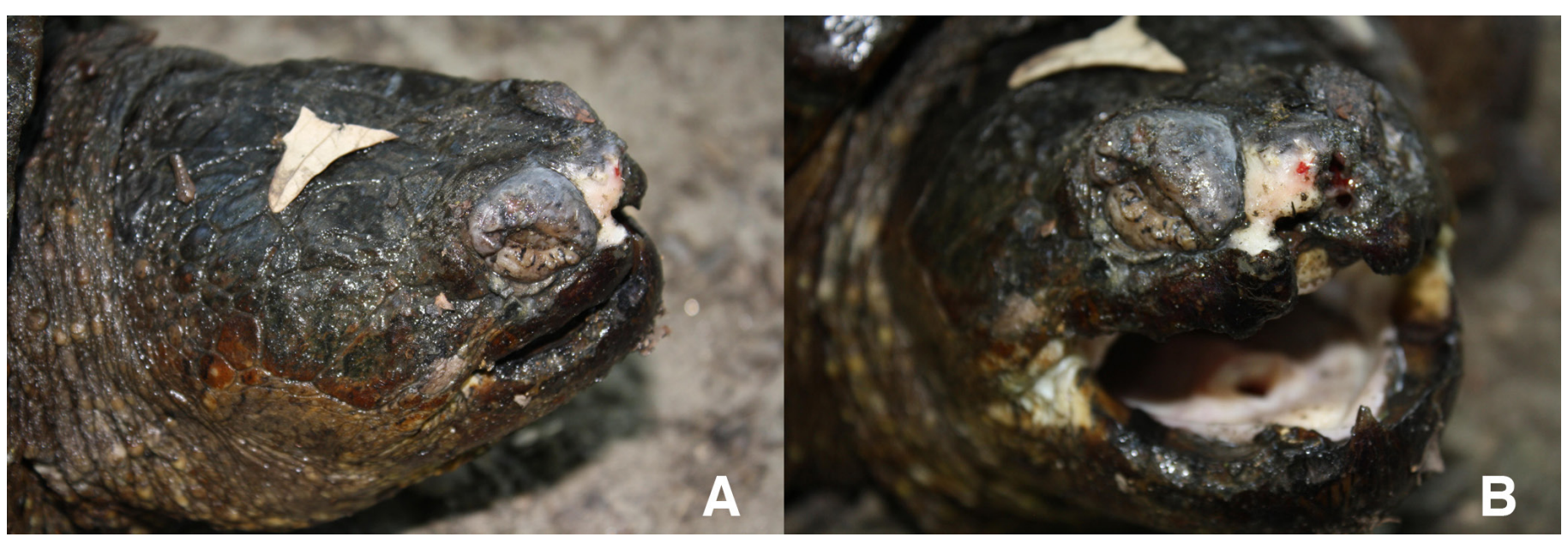

Fig. 5. An adult male Common Snapping Turtle (Chelydra serpentina) from the Bronx River (M1). The entire front of the face was deteriorated, the eyes were swollen shut, and the nose was entirely missing.

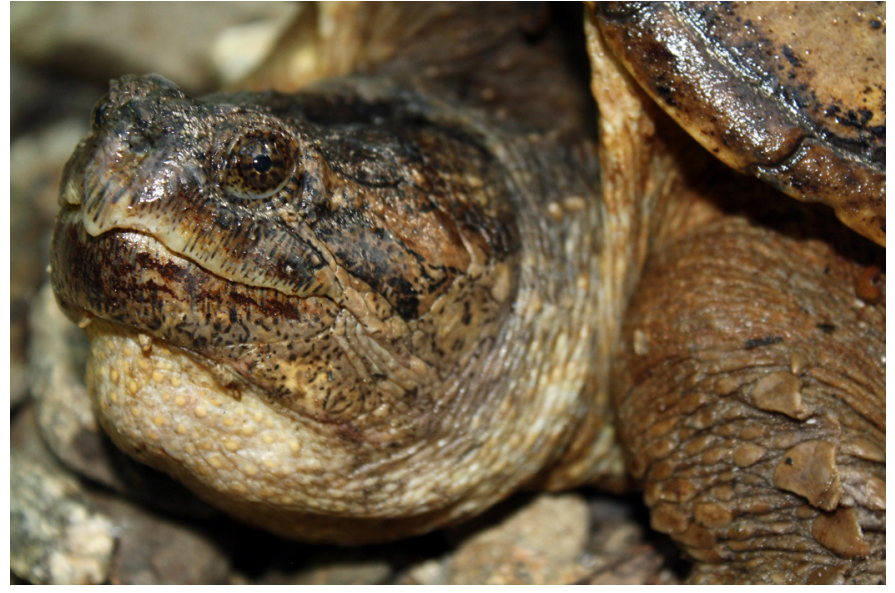

Fig. 6. An adult female Common Snapping Turtle (Chelydra serpentina) from the Bronx River (F1). Facial abnormalities were limited.
(Table 2). I also examined snapping turtles from elsewhere in the Bronx, but observed no major facial deformities in those populations.

\section{Discussion}

Given the appearance of open lesions on adults, I doubt that they resulted from injuries to turtles when they were juveniles. Some individuals were thought at first to have lost facial tissue as a consequence of injuries inflicted by other snapping turtles, perhaps during male-male combat (e.g., Brown and Brooks 1993), predation attempts, or encounters with fish hooks. However, virtually no fishing occurs at these sites in protected city parks, and the skull of adult snapping turtles presumably is tough enough to withstand even the powerful bite of conspecifics without tissue damage to the extent noted in this report. 
Table 2. Other observed deformities, Bronx River and Twin Lakes populations.

\begin{tabular}{lcccl}
\hline ID & Sex & Carapace length $(\mathbf{c m})$ & Mass & Description of deformity $(\mathbf{k g})$ \\
\hline 41 & F & 29.21 & 5.45 & Section of nose missing \\
\hline 37 & $?$ & 19.05 & 1.40 & Aberration/deformity on tip of tail \\
\hline 45 & F & 30.48 & 5.00 & Reversed claw on upper left foot \\
\hline 51 & M & 34.29 & 9.99 & Extra tail spines, spines appear deformed \\
\hline 67 & F & 25.4 & 4.09 & Tail shortened, ends in a growth/aberration \\
\hline 72 & F & 27.94 & 4.54 & Tumor/growth on left side of lower jaw \\
\hline 39 & M & 35.56 & 9.99 & Half of tail missing (bifid tail regeneration) \\
\hline
\end{tabular}

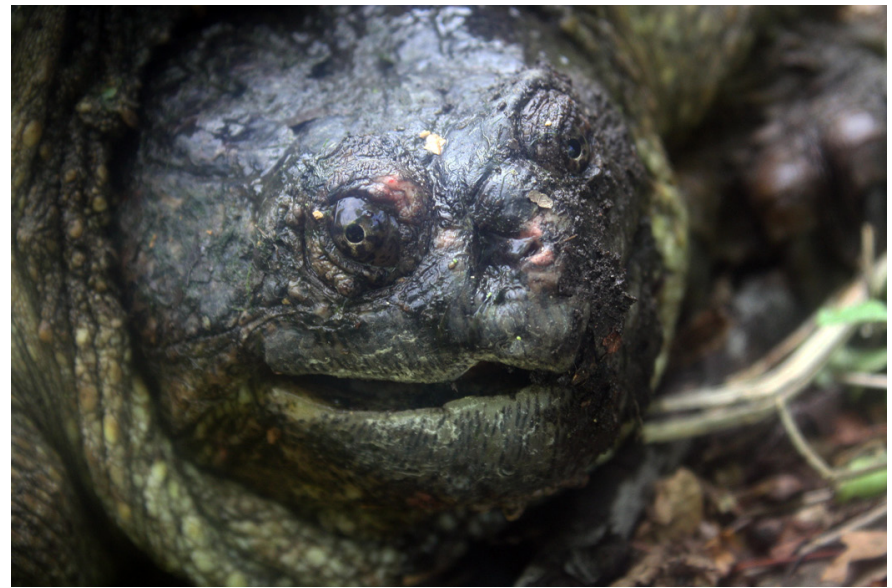

Fig. 7. An adult male Common Snapping Turtle (Chelydra serpentina) from Twin Lakes (M2). Facial deformities were minimal, but the shell shape was abnormal. The carapace was raised high above the body and did not reflect the more "streamlined" shell structure seen in most aquatic turtles.

Although Bronx River drainage water quality in terms of dissolved $\mathrm{O}_{2}$, turbidity, etc. was deemed generally good in the sections above and including the Bronx Zoo (USACE 2006), the water quality parameters measured were by no means extensive. The river has had periodic problems resulting from storm runoff with accompanying bank damage, sedimentation, and untreated sewage discharge (Crimmens and Larson 2006). As of 2003, the Bronx River contained significant amounts of PCB mixtures (primarily Aroclors and congeners; Litten 2003) and "average" total dioxin-like toxic equivalents (TEQ), although higher accumulations were recorded below the Bronx Zoo (Rodenburg et al. 2011). The considerable urbanization within the drainage suggests potential for contamination (at least seasonally) at my down-stream sites, and I suggest that these could cause developmental anomalies in snapping turtles.

However, although deformities in turtles often result from chemical pollution (Bell et al. 2006), verification is difficult. Abnormalities resulting from environmental PCBs and related pollutants seem to originate during embryogenesis prior to hatching (Bell et al. 2006, Holliday and Holliday 2011), occur in the population at percentages greater than I observed, and are not of necrotic nature. Also important is the fact that the necrosis I recorded affected only the areas around the nose. This might be attributable to the fact that the turtles in my study area spend a great deal of time using their noses to forage in mud (pers. obs.), which might harbor a pathogen or unknown toxic substances. Recaptures of M1 were indicative of advancing facial necrosis, and this was the first individual found exhibiting what I termed "mid-infection," suggesting that this condition is due at least in part to some fungal and/or bacterial pathogen. Also, my observations of that individual suggest that any such pathogen has active and inactive phases. Observations of specimen M4 (Table 1a $\&$ b) indicated that damage can persist throughout life.

Although a highly speculative assumption, but because all five turtles (especially the males) are in the same general size class, and because they have other deformities, a singlepoint influx of a chemical contaminant might have caused one season's eggs to hatch with developmentally deformed young of which these animals are among the sole survivors.

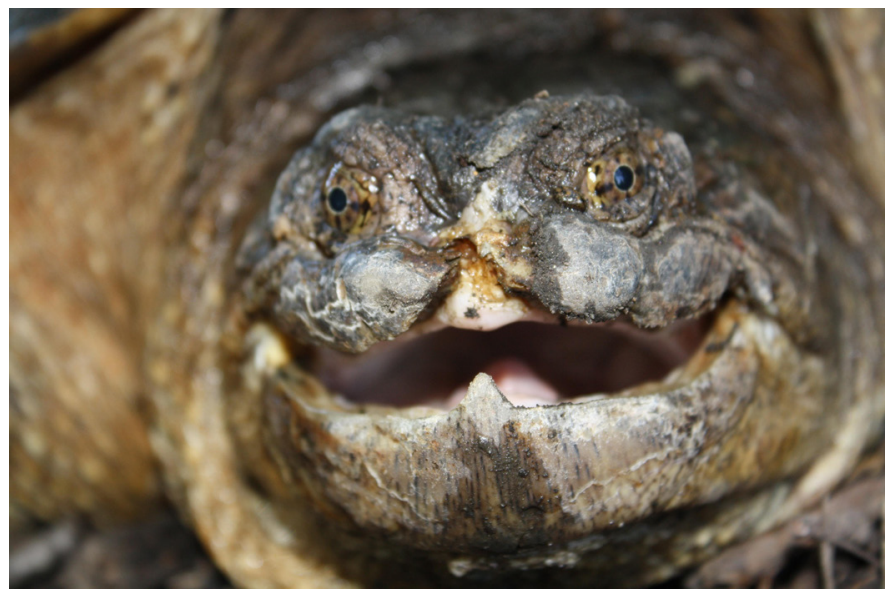

Fig. 8. An adult male Common Snapping Turtle (Chelydra serpentina) from the Bronx River (M4). In addition to facial deformities, portions of the shell were discolored and included necrotic areas. 


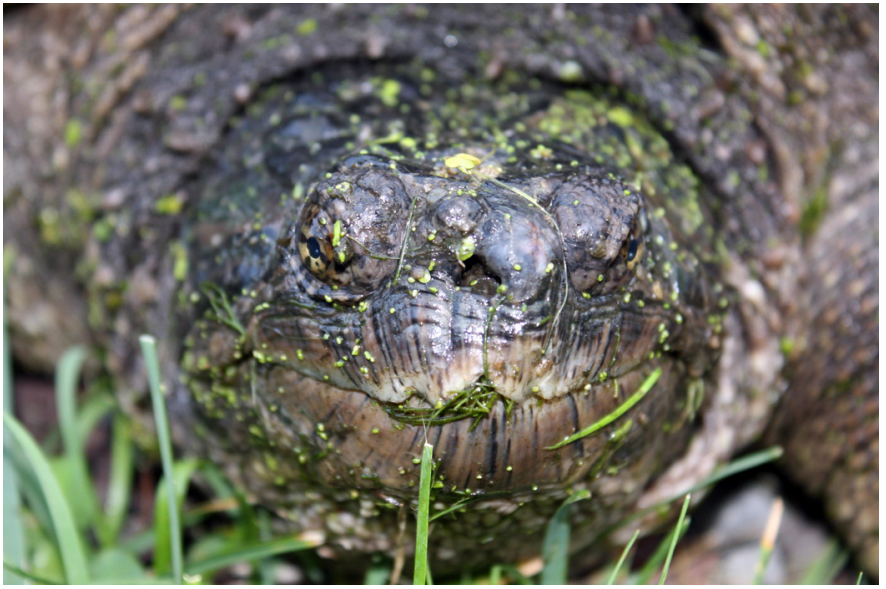

Fig. 9. An adult male Common Snapping Turtle (Chelydra serpentina) from Twin Lakes (M3). Facial abnormalities were severe and the left front foot was deformed (Fig. 10).

Consequently, the conditions I observed might be the result of these turtles having hatched with facial deformities that have made them more susceptible over time to various infections as they forage.

PCBs or other toxins might result in immuno-compromise (Keller et al. 2006), rendering exposed individuals more susceptible to infections that would quickly heal under "normal" conditions. No tissue or blood samples have as yet been taken from these turtles, although the study is ongoing. Hence, any conclusions drawn about the causes of these facial deformities are at present speculative. However, nothing like the conditions observed in $C$. serpentina from the lower Bronx River has been previously documented. Searches at http:// scholar.google.com using several combinations of keywords (Chelydra, facial, necrosis, turtles, mycotic, diseases, abnormal, lesion, bone, pathology, nose) returned no significant references beyond those cited herein.

Further studies are plainly needed to fully understand the causes of these conditions. Whatever the cause, this highly resilient and hardy species is able to survive after being afflicted, which is remarkable considering that Chelydra serpentina relies heavily on its sense of smell (Steyermark et al. 2008). Two turtles with the most severe cases even managed to navigate around or over a waterfall between recaptures. They possibly have been living with this condition for years, demonstrating that even in the midst of urban New York City, exceptional species are able to overcome the challenges of living among humans.

\section{Acknowledgements}

I thank the following institutions and organizations for allowing me to conduct research on their grounds, and for their logistic support: New York Botanical Gardens, Bronx Zoo, New York City Department of Parks and Recreation, Bronx River Alliance, and New York City Urban Park Rangers. My

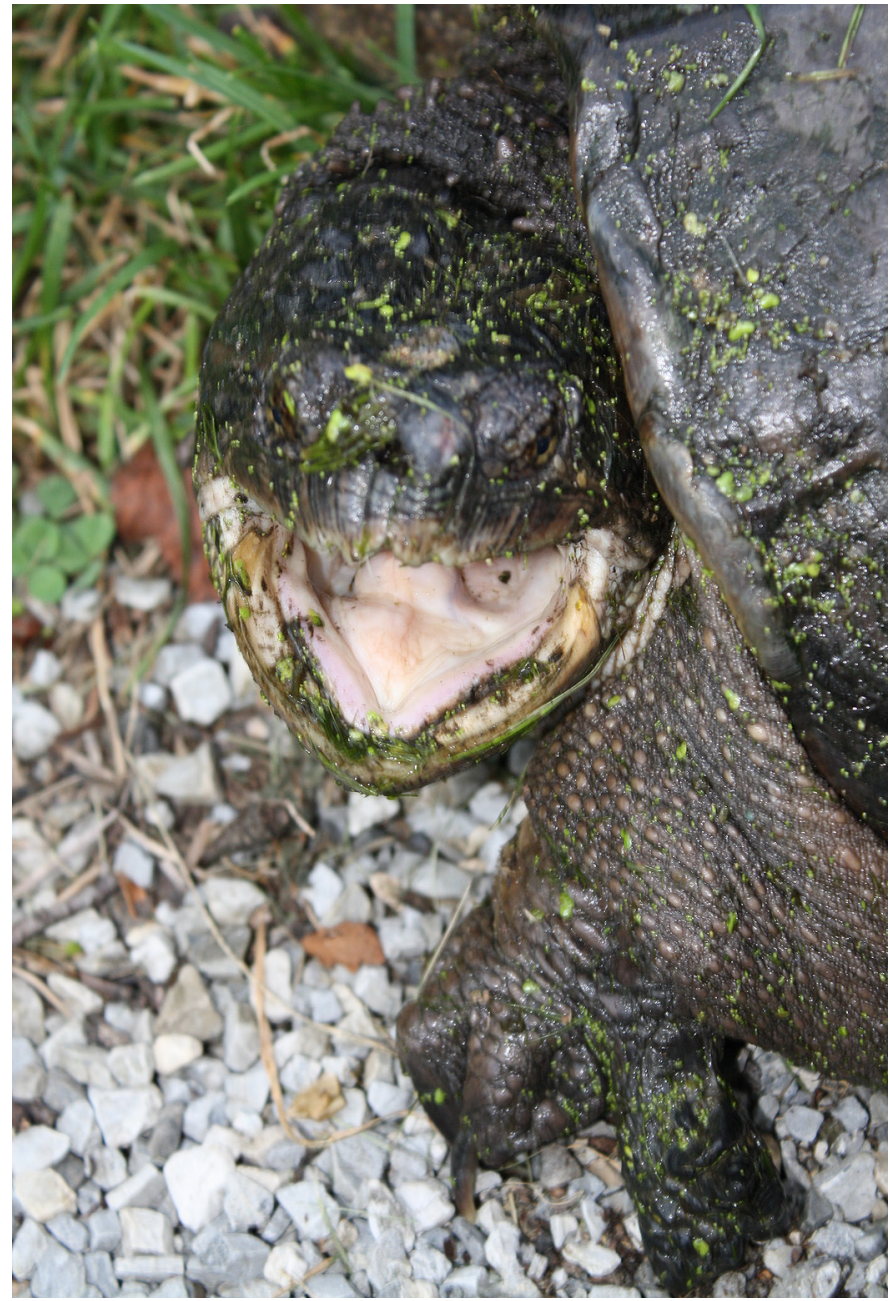

Fig. 10. The left front foot of an adult male Common Snapping Turtle (Chelydra serpentina) from Twin Lakes (M3). Digits 1-3 were fused and digits 4 and 5 were barely recognizable and were fused in a fleshy mass.

good friend Lee Veitch assisted with fieldwork. Jessica Sheuler of the New York Botanical Gardens enthusiastically supported my fieldwork within the New York Botanical Gardens. My parents, Rick and Eileen Zeidler, provided transportation for this project and I also thank them for supporting their young son's passion. Jenny Pramuk (formerly Herpetology Curator, Bronx Zoo) and The Bronx High School of Science gave helpful support and guidance during this project. I am grateful to The American Museum of Natural History for awarding me the 2010 Young Naturalist Award for this study. The New York Times and the Daily News provided media coverage. I especially thank George R. Pisani (Kansas Biological Survey), without whose help this could not have been written, for helpful comments regarding content and format of this report, as well as with statistics.

\section{Literature Cited}

Bell, B., J.R. Spotila, and J. Congdon. 2006. High incidence of deformity in aquatic turtles in the John Heinz National Wildlife Refuge. Environmental Pollution 142:457-465. 
Brown, G.P. and R.J. Brooks. 1993. Sexual and seasonal differences in activity in a northern population of Snapping Turtles, Chelydra serpentina. Herpetologica 49:311-318.

Cagle, F.R. 1939. A system of marking turtles for future identification. Copeia 1939:170-173.

Croteau, M.C., N. Hogan, J.C. Gibson, D. Lean, and V.L. Treaudeau. 2008. Toxicological threats to amphibians and reptiles in urban environments, pp. 197-209. In: J.C. Mitchell, R.E. Jung Brown, and B. Bartholomew (eds.), Urban Herpetology. Herpetological Conservation, vol. 3. Society for the Study of Amphibians and Reptiles, Salt Lake City, Utah.

Holliday, D.K. and C.M. Holliday. 2012. The effects of the organopollutant PCB 126 on bone density in juvenile Diamondback Terrapins (Malaclemys terrapin). Aquatic Toxicology 109:228-233.

Jacobson, E.R., J.L. Cheatwood, and K. Maxwell. 2000. Mycotic diseases of reptiles. Seminars in Avian and Exotic Pet Medicine 9:94-101.

Keller, J.M., P.D. McClellan-Green, J.R. Kucklick, D.E. Keil, and M.M. PedenAdams. 2006. Effects of organochlorine contaminants on Loggerhead Sea Turtle immunity: Comparison of a correlative field study and in vitro exposure experiments. Environmental Health Perspectives 114:70-76.
Litten, S. 2003. Contaminant Assessment and Reduction Project: Water. Final Report, Bureau of Water Assessment and Management, New York State Department of Environmental Conservation, Albany.

McArthur, S., R. Wilkinson, and J. Meyer. 2010. Medicine and Surgery of Tortoises and Turtles. Wiley-Blackwell Publishing, Hoboken, New Jersey.

Mifsud, D.A. and R. Mifsud. 2008. Golf courses as refugia for herpetofauna in an urban river floodplain, pp. 303-310. In: J.C. Mitchell, R.E. Jung Brown, and B. Bartholomew (eds.), Urban Herpetology. Herpetological Conservation, vol. 3. Society for the Study of Amphibians and Reptiles, Salt Lake City, Utah.

Rodenburg, L.A., D. Songyan, X. Baohua, and D.E. Fennell. 2011. Source apportionment of polychlorinated biphenyls in the New York/New Jersey Harbor. Chemosphere 83:792-798.

Steyermark, A.C., M.S. Finkler, and R.J. Brooks (eds.). 2008. Biology of the Snapping Turtle (Chelydra serpentina). Johns Hopkins University Press, Baltimore, Maryland.

USACE (U.S. Army Corps of Engineers). 2006. Bronx River ecosystem restoration project, water quality and biological baseline data collection, Westchester and Bronx counties, New York. Final data and documentation report. U.S. Army Corps of Engineers, New York, New York. 